\title{
Malaria diagnosis from pooled blood samples: comparative analysis of real-time PCR, nested PCR and immunoassay as a platform for the molecular and serological diagnosis of malaria on a large-scale
}

\author{
Giselle FMC Lima ${ }^{1,5} /{ }^{+}$, José E Levi ${ }^{2,3}$, Marcelo P Geraldi ${ }^{3}$, Maria Carmen A Sanchez ${ }^{4}$, \\ Aluísio AC Segurado ${ }^{5}$, Angélica D Hristov', Juliana Inoue ${ }^{1,5}$, \\ Maria de Jesus Costa-Nascimento ${ }^{1}$, Silvia M Di Santi ${ }^{1,5}$ \\ ${ }^{1}$ Núcleo de Estudos em Malária, Superintendência de Controle de Endemias, \\ Secretaria de Estado da Saúde de São Paulo, São Paulo, SP, Brasil ${ }^{2}$ Banco de Sangue do Hospital Sírio Libanês, São Paulo, SP, Brasil \\ ${ }^{3}$ Laboratório de Virologia ${ }^{4}$ Laboratório de Soroepidemiologia e Imunobiologia, Instituto de Medicina Tropical de São Paulo \\ ${ }^{5}$ Departamento de Moléstias Infecciosas e Parasitárias, Faculdade de Medicina, Universidade de São Paulo, \\ Av. Dr. Enéas de Carvalho Aguiar 470/107, 05403-000 São Paulo, SP, Brasil
}

\begin{abstract}
Malaria diagnoses has traditionally been made using thick blood smears, but more sensitive and faster techniques are required to process large numbers of samples in clinical and epidemiological studies and in blood donor screening. Here, we evaluated molecular and serological tools to build a screening platform for pooled samples aimed at reducing both the time and the cost of these diagnoses. Positive and negative samples were analysed in individual and pooled experiments using real-time polymerase chain reaction (PCR), nested PCR and an immunochromatographic test. For the individual tests, $46 / 49$ samples were positive by real-time PCR, $46 / 49$ were positive by nested PCR and 32/46 were positive by immunochromatographic test. For the assays performed using pooled samples, 13/15 samples were positive by real-time PCR and nested PCR and 11/15 were positive by immunochromatographic test. These molecular methods demonstrated sensitivity and specificity for both the individual and pooled samples. Due to the advantages of the real-time PCR, such as the fast processing and the closed system, this method should be indicated as the first choice for use in large-scale diagnosis and the nested PCR should be used for species differentiation. However, additional field isolates should be tested to confirm the results achieved using cultured parasites and the serological test should only be adopted as a complementary method for malaria diagnosis.
\end{abstract}

Key words: malaria - real-time PCR - nested PCR - Plasmodium - diagnosis

The diagnosis of malaria has classically been made following the observation of parasites in thick blood smears stained with Giemsa (Ross 1903) and the determination of the malaria species is essential for the correct treatment, prognosis and monitoring of the patient (WHO 1988). However, the sensitivity of this technique depends on the experience of the microscopist and it can detect between five-50 parasites per microliter of blood (Moody 2002). The time that is required to examine a slide and the low sensitivity of this technique makes this method impractical for the processing of large numbers of samples. Even when evaluated at qualified centers, the thick blood film technique cannot always differentiate between Plasmodium species with similar morphology, which is the case for Plasmodium vivax and Plasmodium ovale (Di Santi et al. 2004).

Financial support: SUCEN/Health Secretariat of the state of São Paulo, Post-Graduation Program in Infectious and Parasitic Diseases/ Tropical Medicine Institute of São Paulo/USP

+Corresponding author: giselledecastro@usp.br

Received 8 February 2011

Accepted 9 August 2011
The increased movement of people due to tourism and business travel into areas with potential malaria transmission requires the attention of haemotherapy services and increased epidemiological surveillance in endemic and non-endemic areas. At blood banks, individuals who report themselves as displaced to endemic areas for malaria are excluded. Nevertheless, this measure may not prevent transfusion transmission because there is often scarce knowledge of malaria in areas without active transmission and because asymptomatic infections in semi-immune individuals are common (Sáez-Alquézar et al. 1998, Kitchen \& Chiodini 2006). According to the Brazilian guidelines (ANVISA 2004) (resolution number 153), endemic areas have been classified as low, medium or high risk areas according to the Annual Parasite Index. Donor candidates from areas of medium and low risk are given thick blood smear or rapid malaria tests before being accepted as donors. Malaria tests are not required in non-endemic areas and this may result in transfusion transmission. The greatest barrier to efficient testing in these regions is the lack of tests that can be applied to large number of samples.

The importance of malaria detection and timely treatment resides primarily in the fact that asymptomatic carriers can serve as a source of infection. This promotes the spread of the disease, which can be the result of both natural and induced transmission. The National Program for Malaria Control in Brazil detected 154 autochthonous 
cases outside the Amazon Region in 2008 and most of these occurred in the Atlantic forest area, where symptomless cases have been described (MS 2010, Couto et al. 2010). Over the past 10 years, four cases of transfusional malaria caused by asymptomatic donors who were displaced to the Atlantic rain forests were confirmed and these cases included one death from infection with Plasmodium malariae (Kirchgatter et al. 2005, Scuracchio et al. 2009). Asymptomatic cases of malaria have also been described in the Brazilian Amazon Region (Oliveira et al. 1995, Alves et al. 2002). Regardless of the level of endemicity, the description of asymptomatic cases in areas of transmission represents a challenge for control strategies, as programs are based on the detection and treatment of symptomatic cases.

Rapid diagnostic tests (RDTs) have emerged as an alternative technique for the detection of parasite antigens (Avila et al. 2002) because they are fast and are easy to perform and interpret. However, their high cost and low sensitivity limit their application (Murray et al. 2003, Belizário et al. 2005, Seed et al. 2005). Immunoassays for antigen detection in whole blood or plasma have been developed, but the sensitivity of these techniques allows the detection of 100-1,000 parasites per microliter of blood, which is lower than that of the thick blood films evaluated by experienced microscopists (Huong et al. 2002).

Of the available methods for antibody detection, the most commonly used are the indirect fluorescent antibody test (IFAT) and the enzyme-linked immunosorbent assay (ELISA). The IFAT is difficult to apply to situations involving large numbers of samples, and although the ELISA is sensitive and suitable for processing large amounts of samples, standardised commercial kits are lacking. Therefore, the use of an immunochromatographic test to detect malaria-specific antibodies may be an alternative technique for the processing of large numbers of samples, which is necessary for blood therapy services and epidemiological studies (Park et al. 2003). The SD Bioline Malaria Pf/Pv (Standard Diagnostics, Inc, Suwon, Korea) is a rapid test for the qualitative detection of IgG, IgM and IgA antibodies specific for Plasmodium falciparum and $P$. vivax antigens. This test uses a recombinant merozoite surface protein (MSP) to detect antibodies against these two species of human parasites in blood, serum or plasma. In a study with samples from patients with positive thick blood smears or polymerase chain reactions (PCR), this test had a sensitivity of $94 \%$ (Costa-Nascimento et al. 2007). As serological tests have good sensitivity in immune individuals, the association of this test with these molecular methods could make it suitable for use in epidemiological studies with large numbers of samples. However, it is important to note that serological tests are suitable for epidemiological studies, but are not suitable for screening donors at blood banks in endemic areas. On the other hand, in non-endemic areas or areas with low prevalence, molecular tests associated with serological assays may be an optimal choice for use in outbreaks and for the screening of donors.

The PCR has high sensitivity and specificity, as well as advantages in the diagnosis of mixed malaria infections (Barker et al. 1994), the detection of asymp- tomatic infections and the screening of blood donors (Kitchen \& Chiodini 2006, Fugikaha et al. 2007). A highly sensitive and specific nested PCR was developed to detect each of the four Plasmodium species that infect humans and this assay can detect one parasite per microliter (Snounou et al. 1993).

The real-time PCR is a fast, automated, accurate and efficient technique for applications with large numbers of samples. This assay demonstrates a high degree of sensitivity and specificity when compared to microscopy (Swan et al. 2005). Moreover, this technique has advantages over the nested PCR. For example, the realtime PCR involves only a single processing step, whereas the nested PCR requires at least two. The real-time PCR is performed in a closed system, which reduces the potential for contamination and dispenses handling of toxic reagents and the agarose gel electrophoresis. Moreover, the results are obtained four times faster than those from a nested PCR and this technique allows the simultaneous detection and quantification of parasites (Perandin et al. 2004). Farcas et al. (2004) demonstrated a correlation between the degree of parasitemia obtained by thick blood smear and the number of gene copies amplified by real-time PCR. Using the thick blood film as a reference, a comparative study between the nested PCR, the multiplex PCR and the real-time PCR found that the latter demonstrated better performance in terms of sensitivity and specificity (Boonma et al. 2007).

Pooled samples were processed as a platform in the study by Bharti et al. (2009), in which two groups of sera with a $1 \%$ and $5 \%$ prevalence of malaria were tested by PCR. The results found that the PCR was able to detect infection in grouped samples using both arrays. As these authors tested the plasma from malaria patients, they suggested that field studies using clinical blood samples would be necessary to validate this platform for pooled samples. Here, we present our results for the analysis of pooled clinical isolates of Plasmodium using molecular and serological tools. This study served as a comparative analysis between molecular techniques (real-time PCR and nested PCR) and a rapid test for the detection of specific antibodies. The results contribute to the development of a screening platform for malaria diagnosis that could be used to test large numbers of samples grouped in pools. By using clinical samples that were diagnosed using the thick smear reference test, we have established a feasible and reproducible alternative technique for use in large-scale studies and with pooled samples that should reduce the time and cost of processing.

\section{MATERIALS AND METHODS}

We assayed clinical samples that were diagnosed using the thick smear reference test (with different parasitemias) according to the prevalence of the species in Brazil (75\% P. vivax, $22 \%$ P. falciparum and $3 \%$ P. malariae). We also collected 48 negative samples from individuals with no history of travel to endemic areas and no previous malaria infections. However, four of these individuals had tested positive for other diseases, including toxoplasmosis, leishmaniasis, hepatitis B and Chagas disease. The 
blood samples were collected in ethylenediamine tetraacetic acid (EDTA) anticoagulant tubes and the plasma was separated and stored at $-20^{\circ} \mathrm{C}$ until future use.

Preparation of the pools - In addition to the individual processing, samples were also pooled into groups of 10 samples. These pools contained one-three samples that were positive for the different Plasmodium species, as well as nine-seven negative samples, and each was placed in a total volume of $3 \mathrm{~mL}$. The rational for pooling 10 samples in each assay was based on the model purposed by Dorfman (1943) for syphilis screening, which consisted of a two-stage minipool algorithm for the processing of 10 samples. This model was also used successfully to screen blood donors for other diseases (Taylor et al. 2010). From a total of 15 pools, 12 contained one positive and nine negative samples each, two contained two positive and eight negative samples and one pool contained three positive and seven negative samples. Pools with only negative samples were used as negative controls. The positive samples used in each of the pools are described in Table I.

DNA extraction - Both the individual samples and the pools were lysed with $1 \%$ saponin (Sigma-Aldrich, Inc, St Louis, MO, USA) prior to DNA extraction with the QIAamp DNA Blood Mini Kit (Qiagen ${ }^{\circledR}$, Valencia, CA, USA) in accordance with the manufacturer's instructions. The DNA was eluted in a final volume of $50 \mu \mathrm{L}$ and was stored at $-20^{\circ} \mathrm{C}$. After the extraction, the DNA was quantified (Eppendorf ${ }^{\circledR}$ BioPhotometer) to determine the amount of DNA and to estimate the level of contamination by proteins. All of the samples had a ratio between 1.5-2 and each had an adequate purity for analysis.

Real-time PCR - The assay used for genus-specific amplification described by Gama et al. (2007) was modified by reducing the reagent volume and increasing the number of cycles to obtain a protocol with a lower cost and a greater sensitivity. The genus-specific M60 and M61 primers and the M62 probe targeted the gene encoding the small subunit $18 \mathrm{~S}$ rRNA of Plasmodium. Briefly, the reaction was prepared using $2.5 \mu \mathrm{L}$ of genomic DNA, $12.5 \mu \mathrm{L}$ of $2 \mathrm{x}$ TaqMan $^{\circledR}$ universal PCR master mix, $500 \mathrm{nM}$ of each primer (M60 and M61) and $300 \mathrm{nM}$ of the M62 probe labeled with FAM ${ }^{\mathrm{TM}}$ and TAMRA ${ }^{\mathrm{TM}}$ (Applied Biosystems, Foster City, CA, USA). The amplification and detection were performed under the following conditions: an initial cycle at $50^{\circ} \mathrm{C}$ for $2 \mathrm{~min}$, a cycle at $95^{\circ} \mathrm{C}$ for 15 min that was followed by 40 cycles at $94^{\circ} \mathrm{C}$ for $30 \mathrm{~s}$ and a final cycle at $60^{\circ} \mathrm{C}$ for $1 \mathrm{~min}$. The samples were assayed in duplicate using the ABI Prism 7300 system (Applied Biosystems).

Analytical sensitivity of the positive control - The sensitivity was assessed using in vitro cultured $P$. falciparum (kindly provided by Dr Maria de Fátima Ferreira da Cruz, Fiocruz, RJ, Brazil) that was serially diluted with uninfected human whole blood (by factors of 10). Also, clinical samples of $P$. vivax and $P$. malariae (with parasitemias calculated per $\mathrm{mm}^{3}$ ) were used for serial dilution to obtain 1 parasite $/ \mathrm{mm}^{3}$ blood. The samples were assayed in triplicate and reproducible $P$. falciparum culture dilutions containing 1 parasite $/ \mathrm{mm}^{3}$ were chosen as positive controls.

Specificity - To assess the specificity, DNA samples from other parasites and viruses (Toxoplasma, Leishmania, Trypanosoma and hepatitis B) were used.

Negative control and internal control - Ultra-pure water or DNA from negative samples were used as negative controls for the real-time PCR. In addition, an internal control was included to test the quality of the DNA through amplification of a sequence of the human $\beta$-globin gene by conventional PCR using the primers GH-20 (59-GAAGAGCCAAGGACAGGTAC) and

TABLE I

Description of clinical Plasmodium isolates used for assembling the pools tested by molecular and serological protocols

\begin{tabular}{|c|c|c|c|c|}
\hline Sample number & Plasmodium species & $\begin{array}{l}\text { TBS parasitaemia }{ }^{a} \\
\left(\mathrm{~mm}^{3}\right)\end{array}$ & Symptoms & Place of infection \\
\hline 03 & P. vivax & 2,880 & Yes & Angola \\
\hline 04 & P. vivax & 6,480 & Yes & Angola \\
\hline 15 & P. malariae & 120 & No & São Paulo (Brazil) \\
\hline 16 & P. malariae & 120 & No & São Paulo (Brazil) \\
\hline 18 & P. vivax & 240 & Yes & São Paulo (Brazil) \\
\hline 21 & P. falciparum & 4,799 & Yes & Angola \\
\hline 22 & P. falciparum & 1,200 & Yes & Nigeria \\
\hline 24 & P. falciparum & 32,400 & Yes & Mato Grosso (Brazil) \\
\hline 29 & P. vivax & 1,920 & Yes & São Paulo (Brazil) \\
\hline 32 & P. vivax & 120 & No & São Paulo (Brazil) \\
\hline 33 & P. vivax & 120 & No & São Paulo (Brazil) \\
\hline 39 & P. vivax & 960 & Yes & Unkown \\
\hline 40 & P. vivax & 8,760 & Yes & Pará (Brazil) \\
\hline
\end{tabular}

$a$ : according to World Health Organization criteria. The initial diagnosis was based on microscopy. TBS: thick blood smear. 
PCO4 (59-CAACTTCATCCACGTTCACC). The reaction conditions were identical to a previously published protocol (Melana et al. 2001).

Nested PCR - The protocol used for the nested PCR was based on that from Snounou et al. (1993) and used genus-specific (rPLU5 and rPLU6) and species-specific (rFAL1, rFAL2, rMAL1, rMAL2, rOVA1, rOVA2, rVIV1 and rVIV2) primers. Briefly, the $25 \mu \mathrm{L}$ of reaction volume per tube consisted of $250 \mathrm{~nm}$ of each primer, $125 \mu \mathrm{M}$ dNTPs, $2 \mathrm{mM} \mathrm{MgCl}_{2}, 50 \mathrm{mM} \mathrm{KCl}, 10 \mathrm{mM}$ Tris $\mathrm{pH}$ 8.3, $0.4 \mathrm{U} \mathrm{Taq}$ polymerase and $1 \mu \mathrm{L}$ of genomic DNA. The samples were subjected to an initial denaturation at $95^{\circ} \mathrm{C}$ for $5 \mathrm{~min}$, a step at $58^{\circ} \mathrm{C}$ for $2 \mathrm{~min}$, a step at $72^{\circ} \mathrm{C}$ for 2 min that was followed by 24 cycles at $94^{\circ} \mathrm{C}$ for $1 \mathrm{~min}$, $58^{\circ} \mathrm{C}$ for $2 \mathrm{~min}, 72^{\circ} \mathrm{C}$ for $2 \mathrm{~min}$ and a final step at $72^{\circ} \mathrm{C}$ for $5 \mathrm{~min}$ in an Eppendorf Mastercycler machine. The second reaction was performed with 30 amplification cycles. All PCR assays included positive controls (genomic DNA from $P$. vivax, $P$. falciparum and $P$. malariae) and negative controls (ultrapure water). The fragments were separated by electrophoresis on a $1.5 \%$ agarose gel in Tris-borate-EDTA buffer and were visualised with ethidium bromide (Biorad, Hercules, CA, USA) or Blue Green (LGC Biotecnologia, Brazil) and ultraviolet light.

Antibody detection - All of the serum samples that tested positive for malaria by thick blood smear as well as a panel of 10 negative samples were tested individually using the SD Bioline Malaria $P f / P v$ test in accordance with the manufacturer's instructions. The test uses recombinant MSP antigens of $P$. falciparum and $P$. vivax and was performed on pools containing positive and negative samples.

\section{RESULTS}

Standardisation of the positive controls in the realtime and the nested PCR - The cultured samples of $P$. falciparum that were serially diluted 10 fold had parasitemias that ranged from 3,600-0.36 parasites $/ \mathrm{mm}^{3}$. The real-time PCR was able to amplify each of the samples and the lowest dilution $\left(3,600\right.$ parasites $\left./ \mathrm{mm}^{3}\right)$ was found to have a cycle threshold $(\mathrm{Ct})$ value of 21.67 , whereas the highest dilution $\left(0.36\right.$ parasite $\left./ \mathrm{mm}^{3}\right)$ was found to have a Ct of 34.22 (Fig. 1). We used a P. falciparum culture sample that contained 1 parasite $/ \mathrm{mm}^{3}$ as a positive control and this was reproducible in all of the trials. The nested PCR was able to amplify samples diluted to 3.6 parasites $/ \mathrm{mm}^{3}$ (Fig. 1).

Standardisation of the negative controls - Each of the 48 samples that were negative for malaria, including those positive for other diseases, were tested by real-time PCR and produced negative results. Eight samples with $\mathrm{Ct}$ values above 38 (considered negative) as well as the four samples positive for other diseases were tested by nested PCR. There was no amplification in any of these, which confirmed the results of the real-time PCR. Using an algorithm to generate 10 random samples (Windows Excel 2007) from the 44 negative malaria samples, we applied these samples to the immunochromatographic SD Bioline Malaria $P f / P v$ test and each of the 10 serum samples produced a negative result.
Internal control - The DNA quality was assessed using the $\beta$-globin (Homo sapiens) gene as an internal control. The results obtained by conventional PCR for this gene were adequate, as each of the isolates were amplified, which indicated that the genomic DNA was extracted properly.

Real-time PCR cut-off determination - The cut-off point was determined using a receiver operating characteristic (ROC) curve (Greiner et al. 2000) of the 49 positive clinical samples and the 48 negative malaria samples as assayed by real-time PCR. This resulted in a $\mathrm{Ct}$ value of 37.28 (Fig. 1), a sensitivity (Se) of $93.88 \%$ and a specificity $(\mathrm{Sp})$ of $100 \%$.

Performance of the real-time PCR, the nested PCR and the SD Bioline Malaria Pf/Pv test compared with the thick blood film - One of the 50 samples positive for malaria by microscopy was excluded from the individual analysis due to problems with the DNA extraction,

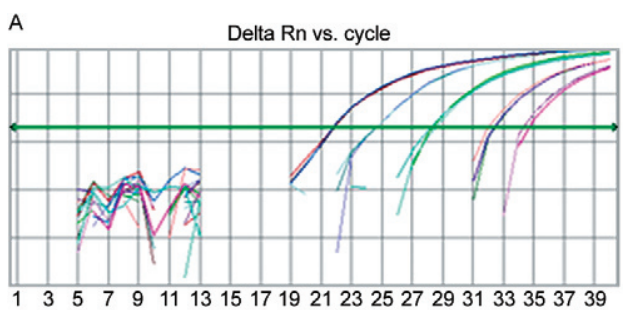

B

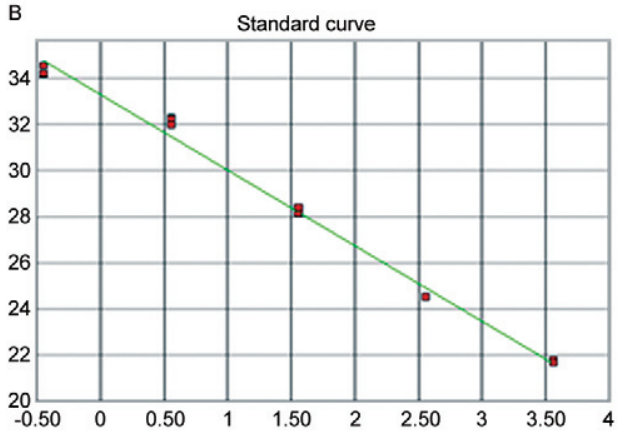

C

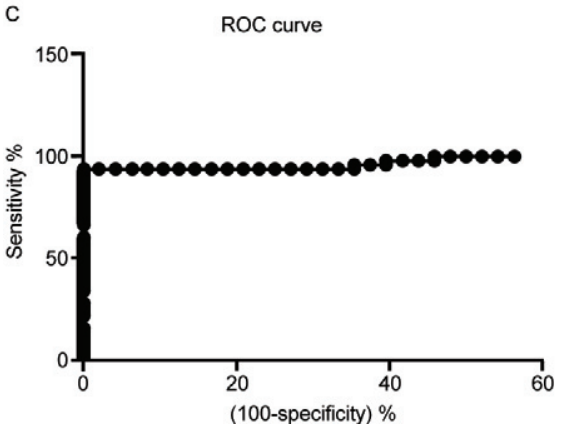

Fig. 1A: real-time polymerase chain reaction with serial dilutions of Plasmodium falciparum culture samples from 3,600-0.36 parasites/ $\mathrm{mm}^{3}$ and cycle threshold $(\mathrm{Ct})$ of 21.7-34.3, respectively; B: standard curve showing the log of parasite initial amount ( $x$-axis) and $\mathrm{Ct}$ (yaxis) with a determination coefficient (R2) of 0.99 and slope -3.2 ; C: receiver operating characteristic (ROC) curve with positive clinical and negative samples for malaria generating a cut-off of 37.28 . 
but this sample was included in the pooled processing. For the statistical analysis, a $95 \%$ confidence interval (CI) was considered significant. By real-time PCR, 46/49 samples tested positive for Plasmodium; the Se was $93.88 \%$ (83.13-98.72) and the Sp was $100 \%$ (92.60100.00). By nested PCR, 46/49 samples tested positive for Plasmodium; the Se was $93.88 \%$ (83.13-98.72) and the $\mathrm{Sp}$ was $100 \%$ (73.54-100.00). Of the 46 samples that were assayed with the SD Bioline Malaria $P f / P v$ test (3 $P$. malariae samples were excluded because the test only detects antibodies against $P$. vivax and $P$. falciparum), $32 / 46$ samples were serologically positive. For this test, the Se was $69.56 \%(54.25-82.26)$ and the $\mathrm{Sp}$ was $100 \%$ (69.15-100.00). As for the results of the nested PCR, one sample that was positive for $P$. vivax by microscopy was found to be positive for $P$. falciparum and $P$. ovale, one sample that was positive for $P$. malariae by microscopy was found to be positive for $P$. vivax and one sample that was positive for $P$. falciparum by microscopy was found to be positive for $P$. falciparum and $P$. vivax.

Comparative performance of the molecular and serological tests - The molecular tests demonstrated a statistically significant greater sensitivity $\left(\mathrm{p} \leq 0.001, \chi^{2}\right.$ test) than the serological test. There were no significant differences in sensitivity between the real-time PCR and the nested PCR ( $\mathrm{p}=1.000$, Fisher's exact test).

Concordance between molecular and serological tests - The real-time PCR and the nested PCR demonstrated an excellent concordance of $96.72 \%$ and a Kappa (к) value of 0.9116 (0.7911-1). The real-time PCR and the SD Bioline Malaria $P f / P v$ test demonstrated a concordance of $81.4 \%$, which was considered regular with a $\mathrm{K}$ value of $0.578(0.353-0.803)$. The nested PCR and the SD Bioline Malaria $P f / P v$ test demonstrated a regular concordance of $80.36 \%$ and a $\mathrm{K}$ value of $0.5361(0.2904$ 0.7818 ). The $\mathrm{K}$ values were considered significant at a $95 \% \mathrm{CI}$ and the interpretation of the values was based on those of Pereira (1995) and Andrade and Zicker (1997).

Comparative aspects of the molecular and serological tests considering individual samples - Of 35 samples diagnosed as $P$. vivax by thick blood film and tested using the molecular and serological tools (Fig. 2), three samples $(8.57 \%)$ had $\mathrm{Ct}$ values above the cut-off by real-time PCR. The nested PCR also failed to amplify three samples $(8.57 \%)$. There was concordance between two of the three negative samples by real-time PCR. Fourteen sera samples (30.43\%) did not react to the antigens in the SD Bioline Malaria $P f / P v$ test. Eleven $P$. falciparum samples and three $P$. malariae samples, which were diagnosed by thick blood film, were assayed by real-time PCR, nested PCR and the SD Bioline Malaria $P f / P v$ test. The real-time PCR results demonstrated amplification for all these samples (Fig. 3). The nested PCR also amplified each of the samples for both species and was also able to detect a mixed infection (P. falciparum plus $P$. vivax) in one sample. The immunochromatographic SD Bioline Malaria $P f / P v$ test failed to detect antibodies in two of the $P$. falciparum samples and this test detected antibodies against $P$. vivax in one of three P. malariae samples (Table II).
Comparative aspects between the molecular and serological testing of pooled samples - We processed 15 pools containing positive and negative samples, as described previously. By real-time PCR, $13 / 15$ pools $(86.66 \%)$ had $\mathrm{Ct}$ values lower than 37.28, which was regarded as the cut-off in this study (Fig. 4). Also, there was gene amplification in the same 13 pools by nested PCR $(86.66 \%)$. The immunochromatographic SD Bioline Malaria $P f / P v$ test had a sensitivity of $73.33 \%$ and detected antibodies in 11 of these samples. The real-time PCR amplified 100\% of the P. falciparum samples, $90 \%$ of the $P$. vivax samples and $100 \%$ of the $P$. malariae samples. The nested PCR amplified $100 \%$ of the P. falciparum samples and $60 \%$ of the $P$. vivax samples. In two of the sample pools, the nested PCR detected P. malariae (pool 9) instead of $P$. vivax and detected the presence of both $P$. falciparum and P. ovale (pool 14). Thus, the ability of this technique to detect infection increased to $80 \%$. The nested PCR found concordance in one of the three pools containing samples

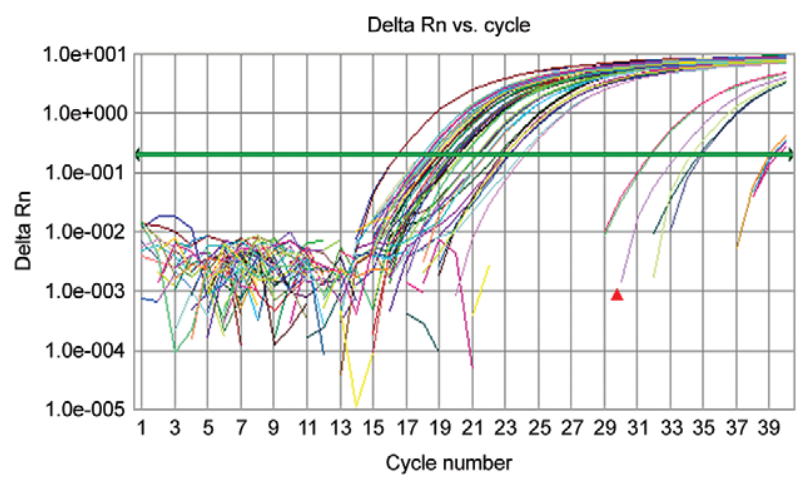

Fig. 2: sensitivity of real-time polymerase chain reaction in samples of Plasmodium vivax showing cycle thresholds and positive control with 1 parasite $/ \mathrm{mm}^{3}(\mathbf{\Delta})$.

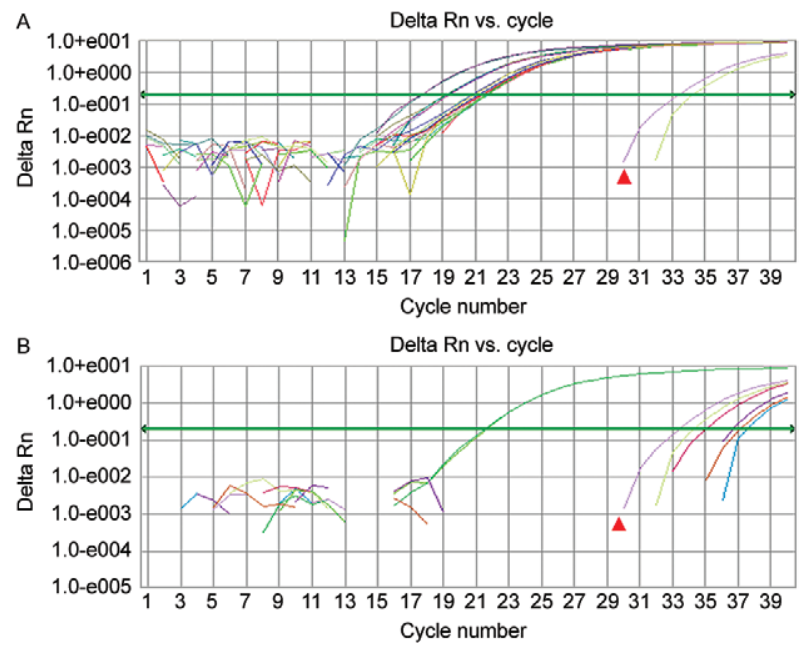

Fig. 3A: sensitivity of real-time polymerase chain reaction performed with samples of Plasmodium falciparum; B: Plasmodium malariae and positive control with 1 parasite $/ \mathrm{mm}^{3}(\boldsymbol{\Lambda})$. 
positive for $P$. malariae by microscopy. The SD Bioline test detected antibodies in five $P$. vivax samples and three $P$. falciparum samples (Table III).

\section{DISCUSSION}

The standard reference method for malaria diagnosis is the thick blood film, but the reduced sensitivity of this test at low parasitemias and the reduced ability of this test to detect mixed infections limit its use in epidemiological or clinical studies and in blood therapy services with large numbers of samples. Because the thick blood film technique requires long periods of observation by highly trained professionals (Kain et al. 1998), there is a need for molecular methodologies based on the amplification of DNA (Snounou et al. 1993, Kimura et al. 1997, Rubio et al. 1999). Gama et al. (2007) modified a realtime PCR protocol (Lee et al. 2002) into a conventional genus-specific PCR that could detect 0.5 parasites $/ \mathrm{mm}^{3}$. Because this modified technique was found to have the same threshold of detection as the real-time PCR, this protocol was adopted for our study.

We used DNA from a $P$. falciparum culture diluted to 1 parasite $/ \mathrm{mm}^{3}$ as a positive control and this was reproducible in each of the real-time PCRs performed. Although we have assayed the clinical samples by serial dilution, the potential bias introduced during the parasitemia counting created a limitation for the use of these field isolates as positive controls. According to the WHO methodology that uses the number of parasites per 100 leucocytes divided by 100 and multiplied by 6,000 leucocytes $/ \mathrm{mm}^{3}$ (OPAS 1975), the parasitemias of the two isolates used ( $1 P$. vivax and $1 P$. malariae) would be 240 and 120 parasites $/ \mathrm{mm}^{3}$, respectively. However, as these two isolates were from asymptomatic patients with a very low parasitemia, the parasites were detected only after observing 10,000 leucocytes (4 parasites in the $P$. vivax sample and 2 in the $P$. malariae sample). Therefore, these clinical isolates had parasitemias of 2.4 and 1.2 parasites $/ \mathrm{mm}^{3}$, respectively.

The cut-off value for this study was calculated based on the ROC curve and resulted in a $\mathrm{Ct}$ value of 37.28. This value indicated a performance that was superior to the values obtained by other authors (Perandin et al. 2004, Veron et al. 2009).

The comparison between the real-time PCR and the thick blood smear, which is considered the reference test for malaria detection, demonstrated a Se of $93.88 \%$ and a Sp of $100 \%$. Other authors have reported slightly higher Se values of $96.6 \%$ (Boonma et al. 2007), 98.5\% (Han et al. 2007) and $99.41 \%$ (Khairnar et al. 2009).

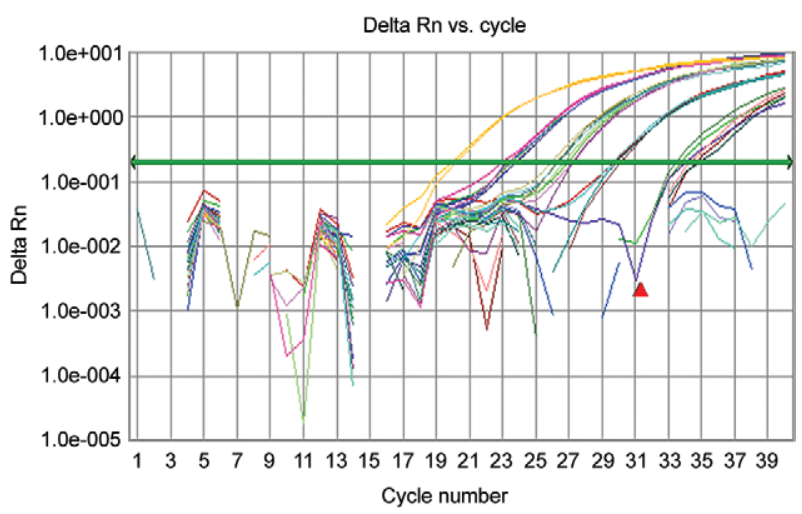

Fig. 4: real-time polymerase chain reaction performed with positive and negative pooled samples with positive control of 1 parasite $/ \mathrm{mm}^{3}(\mathbf{\Delta})$.

TABLE II

Results of real-time polymerase chain reaction (PCR), nested PCR and immunochromatographic SD Bioline Malaria $P f / P v$ in blood samples positive for Plasmodium falciparum, Plasmodium vivax and Plasmodium malariae by microscopy assayed individually

\begin{tabular}{|c|c|c|c|}
\hline Microscopy (n) & Nested $\mathrm{PCR}^{a}$ & SD Bioline $P f / P v$ & Real-time $\mathrm{PCR}^{b}$ \\
\hline$P v(35)$ & $\begin{array}{c}P v(30 / 35) \\
P o+P f(1 / 35) \\
P m(1 / 35) \\
\operatorname{Neg}(3 / 35)\end{array}$ & $\begin{array}{c}P v(22 / 35) \\
P v+P f(1 / 35) \\
P f(3 / 35) \\
\operatorname{Neg}(9 / 35)\end{array}$ & Plasmodium $(32 / 35)$ \\
\hline$P f(11)$ & $\begin{array}{c}P f(10 / 11) \\
P f+P v(1 / 11)\end{array}$ & $\begin{array}{c}P f(8 / 11) \\
P f+P v(1 / 11) \\
P v(1 / 11) \\
\operatorname{Neg}(1 / 11)\end{array}$ & Plasmodium (11/11) \\
\hline$P m(3)$ & $P m(3 / 3)$ & $\begin{array}{c}P v(1 / 3) \\
\operatorname{Neg}(2 / 3)\end{array}$ & Plasmodium (3/3) \\
\hline Neg (48) & Neg $(12 / 12)$ & Neg $(10 / 10)$ & Neg (48/48) \\
\hline Total (97) & 61 & 59 & 97 \\
\hline
\end{tabular}

a: specie-specific; $b$ : genus-specific; Pf: P. falciparum; Pm: P. malariae; Po: P. ovale; Pv: P. vivax. Negative (Neg) samples were assayed for specificity analyses. 
The specificity of our results using these techniques reached $100 \%$, which is greater than the previously described values $89.4 \%$ (Boonma et al. 2007), 94.3\% (Han et al. 2007) and 90.88\% (Khairnar et al. 2009).

The nested PCR in our study had a Se of $93.88 \%$. This is comparable to the published value of $94.3 \%$ (Han et al. 2007) and is generally greater than the values reported by other authors. Others have found a Se of $96 \%$ in cases where the parasitemia was $\geq 500$ parasites $/ \mathrm{mm}^{3}$ and a Se of only $20 \%$ in cases where the parasitemia was under 500 parasites $/ \mathrm{mm}^{3}$ (Coleman et al. 2006). These authors reported a $\mathrm{Sp}$ of $98 \%$, which is lower than the $100 \% \mathrm{Sp}$ obtained in our tests. The nested PCR used in this study (Snounou et al. 1993) provided a more accurate differentiation of the Plasmodium species, which contributed to the detection of mixed infections that were not found by microscopy. This advantage of the nested PCR makes this protocol suitable for use following evaluation by genus-specific real-time PCR (Gama et al. 2007) and makes the screening of large numbers of samples more efficient and economical.

In regard to the failures of the molecular detection techniques, three samples diagnosed as $P$. vivax by thick blood smear tested negative by real-time PCR, as these had $\mathrm{Ct}$ values above the cut-off. However, it is important to note that two of these samples had very low parasitemias; one had a parasitemia of 240 parasites $/ \mathrm{mm}^{3}$ and one had a parasitemia of 120 parasites $/ \mathrm{mm}^{3}$ by thick blood smear, according to the WHO criteria. Therefore, according to our calculation cited above, these samples had parasitemias of 2.4 and 1.2 parasites $/ \mathrm{mm}^{3}$ and only one $P$. vivax sample with a $\mathrm{Ct}$ value above the cut-off could be demonstrated as having failed detection by the molecular techniques.

The SD Bioline Malaria $P f / P v$ test demonstrated a Se of $69.56 \%$ and a Sp of $100 \%$. The results described by Jeremiah et al. (2007) on P. falciparum samples demonstrated Se of $47 \%$ and a Sp of $100 \%$. In our experience, the SD Bioline Malaria $P f / P v$ test failed to detect antibodies to $P$. vivax or $P$. falciparum in 14 samples. Of these, five were from prime-infected patients who had been administered treatment at the onset of symptoms and this treatment may explain the absence of specific antibodies detected. In a sample diagnosed with $P$. vivax by microscopy, the nested PCR detected $P$. ovale that was associated with P. falciparum. This may justify the single positive result for $P$. falciparum, as the device uses $P$. vivax recombinant antigens that are unable to react with the anti- $P$. ovale antibodies. In another sample that was positive for $P$. vivax by microscopy, the nested PCR detected $P$. malariae and this may explain why this sample was not reactive in the antibody test. The comparison of the Se between the molecular and the serological tests showed a statistically significant difference and a regular concordance. The RDT had a Se of $69.56 \%$ and a $\mathrm{Sp}$ of $100 \%$, while the ELISA test developed by Oh et al. (2008) that used recombinant $P$. vivax MSP1 and circumsporozoite surface antigens had a Se of 53\% and a Sp of $94 \%$ when compared with microscopy and the nested PCR. Upon comparison of the two molecular assays, there was no statistically significant difference and there was an excellent concordance, which is similar to results of Perandin et al. (2004). The pooled

\section{TABLE III}

Results of real-time polymerase chain reaction (PCR), nested PCR and immunochromatographic SD Bioline Malaria $P f / P v$ in pooled samples performed with positive (Plasmodium falciparum, Plasmodium vivax, Plasmodium malariae or Plasmodium ovale) and negative samples diagnosed individually by microscopy (WHO criteria)

\begin{tabular}{|c|c|c|c|}
\hline $\begin{array}{l}\text { Assembly of the pools } \\
\text { (microscopy as reference) }\end{array}$ & Real-time $\mathrm{PCR}^{a}$ & Nested PCR ${ }^{b}$ & SD Bioline $P f / P v$ \\
\hline$P v\left(960 / \mathrm{mm}^{3}\right)+\operatorname{Neg}(9)$ & Plasmodium & $P v$ & $P v$ \\
\hline$P v\left(240 / \mathrm{mm}^{3}\right)+\operatorname{Neg}(9)$ & Neg & Neg & Neg \\
\hline$P v\left(8,760 / \mathrm{mm}^{3}\right)+\operatorname{Neg}(9)$ & Plasmodium & $P v$ & Neg \\
\hline$P m\left(120 / \mathrm{mm}^{3}\right)+\operatorname{Neg}(9)$ & Neg & Neg & Neg \\
\hline$P v\left(120 / \mathrm{mm}^{3}\right)+2 P m\left(120 / \mathrm{mm}^{3}\right)+\operatorname{Neg}(7)$ & Plasmodium & $P v$ & $P v$ \\
\hline$P v\left(120 / \mathrm{mm}^{3}\right)+\operatorname{Neg}(9)$ & Plasmodium & $P v$ & $P v$ \\
\hline $\operatorname{Pf}\left(1,200 / \mathrm{mm}^{3}\right)+\mathrm{Neg}(9)$ & Plasmodium & $P f$ & $P f$ \\
\hline $\operatorname{Pf}\left(4,800 / \mathrm{mm}^{3}\right)+\operatorname{Neg}(9)$ & Plasmodium & Pf & Pf \\
\hline$P v\left(6,480 / \mathrm{mm}^{3}\right)+\operatorname{Neg}(9)$ & Plasmodium & $P m$ & $P f$ \\
\hline$P v\left(240 / \mathrm{mm}^{3}\right)+P f\left(1,200 / \mathrm{mm}^{3}\right)+\mathrm{Neg}(8)$ & Plasmodium & $P f$ & $P f$ \\
\hline$P f\left(32,400 / \mathrm{mm}^{3}\right)+\operatorname{Neg}(9)$ & Plasmodium & Pf & $P v$ \\
\hline$P v\left(1,920 / \mathrm{mm}^{3}\right)+\operatorname{Neg}(9)$ & Plasmodium & $P v$ & $P v$ \\
\hline$P m\left(120 / \mathrm{mm}^{3}\right)+\operatorname{Neg}(9)$ & Plasmodium & $P m$ & Neg \\
\hline$P v\left(2,880 / \mathrm{mm}^{3}\right)+\operatorname{Neg}(9)$ & Plasmodium & $P o+P f$ & Pf \\
\hline $2 P v\left(120 / \mathrm{mm}^{3} ; 960 / \mathrm{mm}^{3}\right)+\operatorname{Neg}(8)$ & Plasmodium & $P v$ & $P v$ \\
\hline
\end{tabular}

a: genus-specific; $b$ : specie-specific; Neg: negative; Pf: P. falciparum; Pm: P. malariae; Po: P. ovale; Pv: P. vivax. 
tests that were performed with positive and negative samples demonstrated a Se of $86.66 \%$ for the two molecular techniques and the thick blood smear was used as a reference for each individual sample. In pools with negative samples, the $\mathrm{Sp}$ was $100 \%$ by real-time PCR. In studies using grouped samples, Taylor et al. (2010) obtained a Se of $95 \%$ and a Sp of $99 \%$ in pools of four samples. These authors obtained a detection threshold of 4 parasites $/ \mathrm{mm}^{3}$ using a pool with one positive and nine negative samples. A study by Bharti et al. (2009) used a modification of the nested PCR technique previously described (Snounou et al. 1993) in serum samples were grouped into pools of between 10-100 samples and the Se was $80 \%$ in the pools of 10 samples. In our pooled tests, we used positive control samples with 1 parasite/ $\mathrm{mm}^{3}$ that validated the results obtained by the molecular assays. From a total of 15 pools used, only two were found to be negative by both PCR protocols and each of these contained positive samples that also failed in regards to gene amplification by individual processing. Similar to the individual samples, these results from the pooled samples suggest that factors such as the parasitemia counting of the clinical samples may have influenced the results, as these isolates were diluted as many as 10 times for the assembly of the pools.

One limitation of our study is that despite the use of the $P$. falciparum cultures as positive control, testing a greater number of clinical samples with low parasitaemias may corroborate the ability of our protocol to detect 1 parasite $/ \mathrm{mm}^{3}$ from field isolates.

Surprisingly, the SD Bioline Malaria $P f / P v$ test demonstrated a slightly greater sensitivity for the pooled samples.

The diagnosis of malaria is a great challenge for the malaria control programs and the limitations of the reference test enhance this difficulty. This diagnostic challenge intensifies when large numbers of samples require processing. Despite their high accuracy, reproducibility and sensitivity, molecular techniques carry a high cost and are best suited for processing samples individually. This makes efficient diagnosis of malaria problematic in epidemiological studies and in the screening of donors for transfusion therapies.

This study presents the results of a screening platform for the molecular and serological diagnosis of malaria on a large scale. Based on these results, we support the use of real-time PCR for the genus-specific screening of samples followed by the use of nested PCR for the identification of the Plasmodium species avoiding the use of the nested PCR for negative samples. The rapid SD Bioline Malaria $P f / P v$ test for antibody detection could be recommended as a complementary method for the detection of malaria infection but not as a unique or primary method.

Our results from the evaluation of pooled samples indicate the suitability of these techniques for use in largescale studies with significant impacts on cost and time. Cost estimates indicate a saving of more than $50 \%$ when the pooled technique is used instead of individual processing (Westreich et al. 2008, Taylor et al. 2010).
Because the results of the pooled assays were comparable to those of the individual analyses, this diagnostic platform could be applied for use on grouped blood samples for haemotherapy services. These molecular techniques may improve detection in areas of low endemicity where cases of transfusion malaria have been reported (Kirchgatter et al. 2005) and where the risk of such transmission is associated with asymptomatic infections mainly caused by $P$. malariae that are difficult to detect by thick blood smear. The application of real-time PCR in haemotherapy, as well as in the control of autochthonous outbreaks, where large number of samples need to be screened is essential to optimise malaria diagnoses.

In conclusion, the real-time PCR performed on pooled samples, which contained both Plasmodiumpositive and negative samples, was shown to be a faster and cheaper technique for processing samples on a large scale. Moreover, this technique did not compromise performance and it efficiently detected malaria even among asymptomatic patients with low parasitemias. The methods used in this study were compared statistically and there was good agreement between the two molecular techniques and a regular agreement between these and the SD Bioline Malaria $P f / P v$ test. Thus, a platform for large-scale malaria diagnosis was validated through the use of an initial screening by real-time PCR on pooled samples to detect Plasmodium, which was followed by the nested species-specific PCR after opening the positive pools. The applicability of this study could be associated with numerous aspects related to malaria control, including epidemiological studies in endemic areas, the monitoring and the surveillance of autochthonous outbreaks in non-endemic regions and areas with low endemicity and the screening of blood donors from largescale sample populations.

\section{ACKNOWLEDGEMENTS}

To MSc Rafael B Bueno, for providing eight samples of $P$. vivax, to Christina RC Toniolo, by reading the slides and sample collection, and for the suggestions made at the Laveran and Deane Seminar.

\section{REFERENCES}

Alves FP, Durlacher RR, Menezes MJ, Krieger H, Silva LH, Camargo EP 2002. High prevalence of asymptomatic Plasmodium vivax and Plasmodium falciparum infections in native Amazonian populations. Am J Trop Med Hyg 66: 639-640.

Andrade ALSS, Zicker F 1997. Métodos de investigação epidemiológicos em doenças transmissíveis, Organização Pan-Americana de Saúde/Fundação Nacional de Saúde, Brasília, p. 33-42.

ANVISA - Agência Nacional de Vigilância Sanitária 2004. Resolução 153. Available from: portal.anvisa.gov.br.

Avila PE, Kirchgatter K, Brunialti KCS, Oliveira AM, Siciliano RF, Di Santi SM 2002. Evaluation of a rapid dipstick test, MalarCheck $^{\mathrm{TM}}$, for the diagnosis of Plasmodium falciparum malaria in Brazil. Rev Inst Med Trop Sao Paulo 44: 293-296.

Barker RH Jr, Banchongaksorn T, Courval JM, Suwonkerd W, Rimwungtragoon K, Wirth DF 1994. Plasmodium falciparum and $P$. vivax: factors affecting sensitivity and specificity of PCRbased diagnosis of malaria. Exp Parasitol 79: 41-49. 
Belizário VY, Pasay CJ, Bersabe MJ, Leon WU, Guerrero DM, Bugaoisan VM 2005. Field evaluation of malaria rapid diagnostic tests for the diagnosis of P. falciparum and non- $P$. falciparum infections. Southeast Asian J Trop Med Public Health 36: 552-561.

Bharti AR, Letendre SL, Patra KP, Vinetz JM, Smith DM 2009. Malaria diagnosis by a polymerase chain reaction-based assay using a pooling strategy. Am J Trop Med Hyg 81: 754-757.

Boonma P, Christensen PR, Suwanarusk R, Price RN, Russell B, LekUthai U 2007. Comparison of three molecular methods for the detection and speciation of Plasmodium vivax and Plasmodium falciparum. Malaria J 6: 124

Coleman RE, Sattabongkot J, Promstaporm S, Maneechai N, Tippayachai B, Kengluecha A, Rachapaew N, Zollner G, Miller RS, Vaughan JA, Thimasarn K, Khuntirat B 2006. Comparison of PCR and microscopy for the detection of asymptomatic malaria in a Plasmodium falciparum/vivax endemic area in Thailand. Malar J 5: 121.

Costa-Nascimento MJ, Lima GFMC, Araújo RAS, Kirchgatter K, Carvalho ME, Pereira BF, Bergara DM, Di Santi SM 2007. Avaliação do teste imunocromatográfico SD Bioline Malaria $\mathrm{Pf} / \mathrm{Pv}$ para detecção de anticorpos em malária utilizando sangue total, soro ou plasma humano. Resumos do XLIII Congresso da Sociedade Brasileira de Medicina Tropical, Campos do Jordão. Rev Soc Bras Med Trop 40: 147.

Couto RA, Latorre MRDO, Di Santi SM, Natal D 2010. Autochthonous malaria notified in the state of São Paulo: clinical and epidemiological characteristics from 1980 to 2007. Rev Soc Bras Med Trop 43: 52-58.

Di Santi SM, Kirchgatter K, Brunialti KCS, Oliveira AM, Ferreira SRS, Boulos M 2004. PCR - Based diagnosis to evaluate the performance of malaria reference centers. Rev Inst Med Trop Sao Paulo 46: 183-187.

Dorfman R 1943. The detection of defective numbers of large populations. Annals Math Stat 14: 436-440.

Farcas GA, Zhong KJY, Mazzulli T, Kain KC 2004. Evaluation of the RealArt Malaria LC real-time PCR assay for malaria diagnosis. J Clin Microbial 42: 636-638.

Fugikaha E, Fornazari PA, Penhalbel RSR, Lorenzetti A, Maroso RD, Amoras JT, Saraiva AS, Silva RU, Bonini-Domingos CR, Mattos LC, Rossit ARB, Cavasini CE, Machado RLD 2007. Triagem molecular de portadores assintomáticos de Plasmodium sp entre bancos de sangue da Região Amazônica brasileira. Rev Inst Med Trop Sao Paulo 49: 1-4.

Gama BE, Silva-Pires FES, Lopes MNR, Cardoso MAB, Britto C, Torres KL, Lima LM, de Souza JM, Daniel-Ribeiro CT, Ferreira-da-Cruz MF 2007. Real-time PCR versus conventional PCR for malaria parasite detection in low-grade parasitemia. Exp Parasitol 116: 427-432.

Greiner M, Pfeiffer D, Smith RD 2000. Principles and practical application of the receiver-operating characteristic analysis for diagnostic tests. Prev Vet Med 45: 23-41.

Han ET, Watanabe R, Sattabongkot J, Khuntirat B, Sirichaisinthop J, Iriko H, Jin L, Takeo S, Tsuboi T 2007. Detection of four Plasmodium species by genus- and species-specific loop-mediated isothermal amplification for clinical diagnosis. $J$ Clin Microbiol 45: $2521-2528$

Huong NM, Davis TM, Hewitt S, Huong NV, Uven TT, Nhan DH, Cong le D 2002. Comparison of three antigen detection methods for diagnosis and therapeutic monitoring of malaria: a field study from southern Vietnam. Trop Med Int Health 7: 304-308.

Jeremiah ZA, Uko EK, Buseri FI, Jeremiah TA 2007. Field evaluation of SD Bioline Malaria $P f / P v$ rapid malaria diagnostic test among asymptomatic malaria infected children in Port Harcourt, Nigeria. Res J Parasitol 2: 39-44.

Kain KC, Harrington MA, Tennyson S, Keystone JS 1998. Imported malaria: prospective analysis of problems in diagnosis and management. Clin Infect Dis 27: 142-149.

Khairnar K, Martin D, Lau R, Ralevski F, Pillai DR 2009. Multiplex real-time quantitative PCR, microscopy and rapid diagnostic immuno-chromatographic tests for the detection of Plasmodium spp: performance, limit of detection analysis and quality assurance. Malar J 8: 284.

Kimura M, Kaneko O, Qing L, Mian Z, Kawamoto F, Wataya Y, Otani S, Yamaguchi Y, Tanabe K 1997. Identification of the four species of human malaria parasites by nested PCR that targets variant sequences in the small subunit rRNA gene. Parasitol Internat 46: 91-95.

Kirchgatter K, Nogueira SL, Padilha A, Curado I, Boulos M, Di Santi SM 2005. Lethal malaria caused by Plasmodium malariae in an asplenic patient in Brazil. British Med J 331: 576-b.

Kitchen AD, Chiodini PL 2006. Malaria and blood transfusion. Vox Sanguinis 90: 77-84.

Lee MA, Tan CH, Aw LT, Tang CS, Singh M, Lee SH, Chia HP, Yap EP 2002. Real-time fluorescence-based PCR for detection of malaria parasites. J Clin Microbiol 40: 4343-4345.

Melana SM, Holland JF, Pogo BGT 2001. Search for mouse mammary tumor virus-like env sequences in cancer and normal breast from the same individuals. Clin Cancer Res 7: 283-284.

Moody A 2002. Rapid diagnostic test for parasites. Clin Microbiol Rev 15: 66-78.

MS - Ministério da Saúde 2010. Brasil. [acessed 2 Mar 2011]. Secretaria de Vigilância em Saúde. Sistema de Informação de Agravos de Notificação-SINAN. Available from: portal.saude.gov.br/portal/arquivos/pdf/situacao da malaria site svs 28 12.pdf.

Murray CK, Bell D, Gasser RA, Wongsrichanalai C 2003. Rapid diagnostic testing for malaria. Trop Med Intern Health 8: 876-883.

Oh JS, Kim JS, Lee CH, Nam DH, Kim SH, Park DW, Lee CK, Lim CS, Park GH 2008. Evaluation of a malaria antibody enzyme immunoassay for use in blood screening. Mem Inst Oswaldo Cruz 103: $75-78$.

Oliveira JPA, Zicker F, Pang L 1995. High prevalence of asymptomatic malaria in gold mining areas in Brazil. Clin Infec Dis 20: 15 .

OPAS - Organização Pan-Americana da Saúde/Organização PanAmericana da Saúde, Repartição Sanitária Pan-Americana, Escritório Regional da Organização Mundial da Saúde 1975. Manual de diagnóstico microscópico da malária, 4th ed., OPAS, Washington, $109 \mathrm{pp}$.

Park SK, Lee KW, Hong SH, Kim DS, Lee JH, Jeon BH, Kim WS, Shin HJ, An SH, Park H 2003. Development and evaluation of an immunochromatographic kit for the detection of antibody to Plasmodium vivax infection in South Korea. Yonsei Med J 44: 747-750.

Perandin F, Manca N, Calderaro A, Piccolo G, Galati L, Ricci L, Medici MC, Arcangeletti MC, Snounou G, Dettori G, Chezzi C 2004. Development of a real-time PCR assay for detection of Plasmodium falciparum, Plasmodium vivax and Plasmodium ovale for routine clinical diagnosis. J Clin Microbiol 42: 1214-1219.

Pereira MG 1995. Epidemiologia: teoria e prática, Guanabara Koogan, Rio de Janeiro, 583 pp.

Ross R 1903. An improved method for microscopical diagnosis of intermittent fevers. Lancet 1: 86-87.

Rubio JM, Benito A, Berzosa PJ, Roche J, Puente S, Subirats M, Lopez-Velez R, Garcia L, Alvar J 1999. Usefulness of seminested 
multiplex PCR in surveillance of imported malaria in Spain. J Clin Microbiol 37: 3260-3604.

Sáez-Alquézar A, Ramos AMSV, Di Santi SM, Branquinho MS, Kirchgatter K, Cordeiro IAC, Murta M, Saraiva JCP, Oliveira SG, Bochetti MGG, Pirolla JA, Guerzoni D, Chamone DAF 1998. Controle da malária transfusional em região endêmica e não-endêmica no Brasil. Rev Soc Bras Med Trop 31: 27-34.

Scuracchio PS, Vieira SD, Dourado DA, Bueno LM, Colella R, Ramos-Sanches E, Sanchez MC, Castro GM, Inoue J, Di Santi SM 2009. Detection of Plasmodium malariae transmitted by blood transfusion in São Paulo, Brazil. Transfusion 49: 233a.

Seed CR, Kitchen A, Davis TM 2005. The current status and potential role of laboratory testing to prevent transfusion-transmitted malaria. Transfus Med Rev 19: 229-240.

Snounou G, Viriyakosol S, Zhu XP, Jarra W, Pinheiro L, do Rosario VE, Thaithong S, Brown KN 1993. High sensitivity of detection of human malaria parasites by the use of nested polymerase chain reaction. Mol Biochem Parasitol 61: 315-320.
Swan H, Sloan L, Muyombwe A, Chavalishewinkoon-Petmitr P, Krudsood S, Leowattana W, Wilairatana P, Looareesuwan S, Rosenblatt J 2005. Evaluation of a real-time polymerase chain reactions assay for diagnosis of malaria in patients from Thailand. Am J Trop Med Hyg 73: 850-854.

Taylor SM, Juliano JJ, Trottman PA, Griffin JB, Landis SH, Kitsa P, Tshefu AK, Meshnick SR 2010. High-throughput pooling and real-time PCR-based strategy for malaria detection. J Clin Microbiol 48: 512-519.

Veron V, Simon S, Carme B 2009. Multiplex real-time PCR detection of $P$. falciparum, $P$. vivax and $P$. malariae in human blood samples. Exp Parasitol 121: 346-351.

Westreich DJ, Hudgens MG, Fiscus SA, Pilcher CD 2008. Optimizing screening for acute human immunodeficiency virus infection with pooled nucleic acid amplification tests. J Clin Microbiol 46: 1785-1792.

WHO - World Health Organization 1988. Malaria diagnosis; memorandum from a WHO meeting. Bull World Health Organ 66: 575-594. 